\title{
Scientific medical journals in Mexico
}

\author{
Alfredo Ulloa-Aguirre, ${ }^{1 *}$ Ana Carolina Sepúlveda-Vildósola, ${ }^{2}$ Moisés Selman-Lama, ${ }^{1}$ Luis Oñate-Oñate, ${ }^{1}$ \\ Alejandro Treviño-Becerra, ${ }^{3}$ Carlos Oropeza-Abúndez, ${ }^{4}$ Sergio Sobrino-Cossío, ${ }^{5}$ \\ Pedro Gutiérrez-Castrellón $n^{5}$ and Héctor Esquivias-Zavala \\ ${ }^{1}$ Revista de Investigación Clínica-Clinical and Translational Investigation; ${ }^{2}$ Archives of Medical Research; ${ }^{3}$ Gaceta Médica de México; ${ }^{4}$ Salud Pública \\ de México; ${ }^{5}$ Cirugía y Cirujanos; ${ }^{6}$ Salud Mental. Mexico City, Mexico
}

\begin{abstract}
This symposium describes the main characteristics of six Mexican scientific journals indexed in Journal Citation Reports: Archives of Medical Research, Revista de Investigación Clínica-Clinical and Translational Investigation, Gaceta Médica de México, Salud Pública de México, Cirugía y Cirujanos and Salud Mental. Particular emphasis is given to their historical and organizational aspects, as well as to their main achievements recognized by the national and international scientific community.
\end{abstract}

KEY WORDS: Medical journals. Archives of Medical Research. Revista de Investigación Clínica-Clinical and Translational Investigation. Gaceta Médica de México. Salud Pública de México. Cirugía y Cirujanos. Salud Mental.

\section{Las revistas científicas médicas en México}

\section{Resumen}

En este simposio se describen las principales características de seis revistas cientificas mexicanas reconocidas por el Journal Citation Reports: Archives of Medical Research, Revista de Investigación Clínica-Clinical and Translational Investigation, Gaceta Médica de México, Salud Pública de México, Cirugía y Cirujanos y Salud Mental. Se hace énfasis en sus aspectos históricos y organizacionales, así como en sus logros principales ante la comunidad científica nacional e internacional.

PALABRAS CLAVE: Revistas médicas. Archives of Medical Research. Revista de Investigación Clínica-Clinical and Translational Investigation. Gaceta Médica de México. Salud Pública de México. Cirugía y Cirujanos. Salud Mental.

\section{Introduction}

Despite the relatively slow development of scientific research in Mexico as a consequence of our late arrival at European culture and lack of scientific tradition, to quote Dr. Ignacio Chávez (1947), Mexican scientific medical journals have a long history and have played a very important role in the dissemination of biomedical and clinical research studies carried out by Mexican researchers. However, since last century's decade of the seventies, research in our country became significantly accelerated with the emergence of the figure of full-time researcher and master's and doctoral programs.

It is undeniable that Mexico has made highly significant contributions to the advance of medicine, which have been published in both national and international journals. The former include Gaceta Médica de México (from 1864 to the present day) and its predecessors, Periódico de la Academia de
Correspondence:

*Alfredo Ulloa-Aguirre

E-mail: aulloaa@unam.mx
Gac Med Mex. 2020;156:607-623

Contents available at PubMed

www.gacetamedicademexico.com

0016-3813/@ 2020 Academia Nacional de Medicina de México, A.C.. Published by Permanyer. This is an open access article under the CC BY-NC-ND license (http://creativecommons.org/licenses/by-nc-nd/4.0/). 
Mégico (1836-1840 and later from 1843 to 1851), Periódico de la Sociedad Filoiátrica de México (18401841 and 1844-1845) and La Unión Médica de México (1856-1858), which document the contributions of Mexican medicine to medical literature of the $19^{\text {th }}$ century, including works by Miguel F. Jiménez in La Unión Médica de México (year 1, number 5, volume 1), Rafael Lucio Nájera in Periódico de la Sociedad Filoiátrica de México (No. 3, 1844) and by many other pioneers of clinical research from the $19^{\text {th }}$ century and first half of the $20^{\text {th }}$, which can be read in the interesting compilation made by Juan Somolinos that was published by the National Autonomous University of Mexico in 1984.

Among the journals of great importance of the first half of the $20^{\text {th }}$ century, Revista Mexicana de Biología (1920-1935) stands out, where illustrious physicians published original studies of great importance. We quote, for example, the articles by Eliseo Ramírez Ulloa on changes in vaginal cytology during the woman's menstrual cycle, published in $1922^{2}$ and $1928,{ }^{3}$ which are works that preceded the famous article by Georgios N. Papanikolaou published in 1933. ${ }^{4}$

Currently, the Mexican Journals of Science and Technology Classification System includes 49 periodicals in the area of Medicine and Health Sciences. Out of these, only seven have an impact factor according to Journal Citation Reports, six of which (Archives of Medical Research, Revista de Investigación Clínica-Clinical and Translational Investigation, Gaceta Médica de México, Salud Pública de México, Cirugía y Cirujanos and Salud Mental) are included in this session. The absence of the seventh journal, Annals of Hepatology, was due to limitations in the time scheduled for the symposium, for which we offer an apology in advance.

\section{Archives of Medical Research}

\section{Ana CARolina SEPÚlVEDA-VILDÓSOLA}

In 1970, Dr. Jorge Martínez Manatou and a group of researchers from the Mexican Institute of Social Security (IMSS - Instituto Mexicano del Seguro Social) started the publication of the journal Archivos de Investigación Médica (Archives of Medical Research), which quickly became a means for the dissemination of scientific studies carried out in Mexico. After Dr. Martínez Manatou, José Luis Mateos Gómez (1971-1976), Fernando
Flores Barroeta and Juan García Ramos (1977), Juan Somolinos Palencia (1977-1991), Luis Benítez Bribiesca (1992-2015) and, as of 2016, Ana Carolina Sepúlveda Vildósola, have been editors of the journal.

In 1992, an office was organized with an exclusive staff for the management of the journal and an editorial committee was formed with researchers from the Mexican Institute of Social Security and other institutions: National Autonomous University of Mexico, Center for Research and Advanced Studies, National Polytechnic Institute and National Health Institutes, for the peer review of received manuscripts. Years later, the submission of manuscripts for review by international peer reviewers was initiated, which enabled reducing review times and endowed editorial reviews with more rigor and thoroughness.

In 1972, it was included in Current Contents with an initial impact factor of 0.25 . In 1994, it was accepted in the Science Citation Index. Currently, it is indexed in Chemical Abstracts, Current Contents/Life Sciences, Medline, Lilacs (Literatura Latino-Americana e do Caribe em Ciências da Saúde), Embase, Science Citation Index, Excerpta Medica and Scopus. Its classification: Medicine, Research \& Experimental.

Initially, the journal was published in Spanish, with an abstract in English subsequently being added, and, as of 1992, publishing all the content in English was decided in order to promote its internationalization. Initially, four issues were published per year, which were distributed by mail to some national libraries. Currently, seven regular issues and one special issue are published per year, with an average of 109 articles/ year. Review articles, original articles (biomedical, clinical and epidemiological), preliminary reports and letters to the editor are published, with relevant topics of global interest being prioritized, including chronic-degenerative diseases $(50 \%$ correspond to cancer, cardiovascular diseases, diabetes mellitus, neurological and kidney diseases). Special issues address diseases that pose major challenges to global health systems, such as atherosclerosis, childhood leukemia, the microbiome, and mental health (Fig. 1).

Editorial processes of the journal have evolved as well. Initially, all editorial work was carried out locally on typewriters of the Research Coordination office and printed at Mexican Institute of Social Security printing facilities. As of 1998, a contract was signed with the Elsevier publishing house for the edition, printing and worldwide distribution of the journal, with the selection of manuscripts being the responsibility of the Mexican Institute of Social Security. From then 


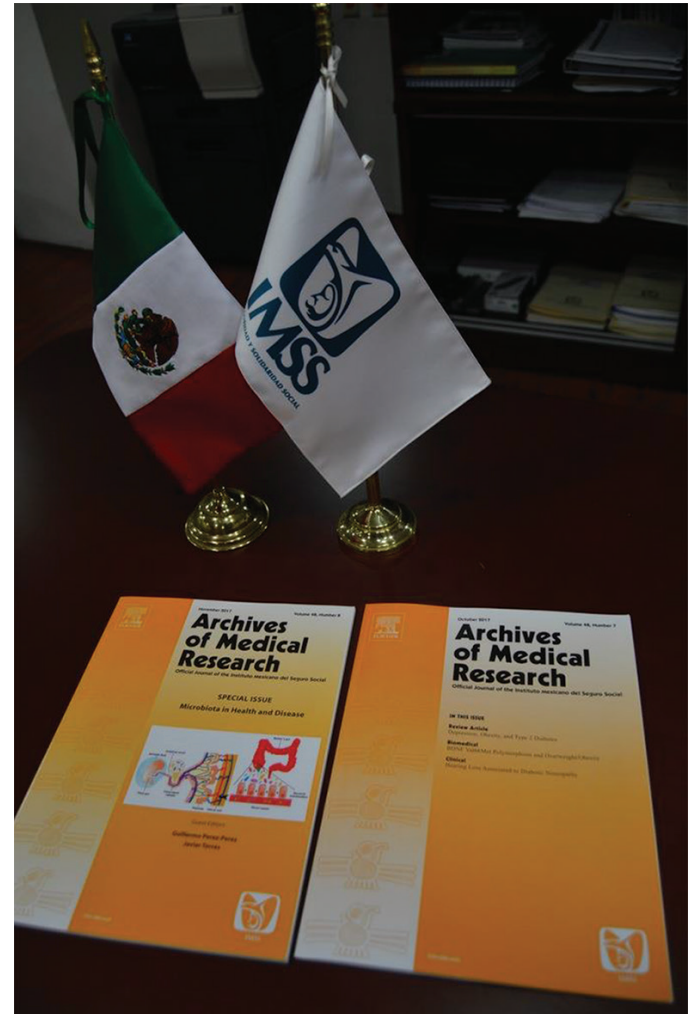

Figure 1. Archives of Medical Research covers.

on, it took the name Archives of Medical Research. Until 2018, the Elsevier Editorial System platform was used for the logistical handling of manuscripts, and from then on, the EVISE (Elsevier) platform is used, which facilitates their handling, allows the detection of plagiarism, suggests reviewers according to the main subject and allows access to Science Direct, among others.

Mexican scientific community response to this editorial effort was initially weak and sometimes of rejection, but as the journal has been internationally positioning itself, the flow of Mexican manuscripts has increased. Currently, approximately $30 \%$ of published articles are of Mexican origin. The success of the journal has allowed manuscripts from a larger number of countries to be increasingly received, with an average of 778 manuscripts per year, originating from 54 countries, among which China, Mexico, the United States, Iran, Brazil and Turkey stand out.

Since 2019, the number of received manuscripts has increased, with an average of 80 per month, and in 2020 , of 119 per month. Initial rejection rate is $68 \%$, and an additional $20 \%$ is rejected after peer review (Fig. 2). All published articles go through a strict review process by thematic experts, with an average of two reviewers per manuscript. These reviewers come from 74 countries; for their participation, they all gain access to Scopus for one month and download a certificate from the platform. Moreover, those who do an outstanding work receive the printed journal for one year. Average time from first submission to acceptance of a manuscript is 16.6 weeks, and for online publication, 19.4 weeks.

Today, the journal is read throughout the world, with the fact that half the manuscript downloads are made in the United States, China, the United Kingdom, Canada and Mexico standing out. Our articles are cited by authors who publish in journals with similar or greater impact factor, such as PLOS ONE, Oncotarget, Scientific Reports Nature, International Journal of Cardiology, Molecular Neurobiology and World Journal of Gastroenterology, among others.

The impact factor (Journal Citation Reports) of the journal went on increasing since 1998, and, in 2016, a historical peak of 2.718 was reached. Over the years, there have been ups and downs and, in the last evaluation, JCR impact factor decreased to 1.895 (Fig. 3), with the journal being ranked 93 among 136 international journals in its category, but it continues to be the Mexican journal with the highest number of citations (3229) and $\mathrm{H}$ index (69). In the Scopus CiteScore ranking, Archives of Medical Research is in the $92^{\text {nd }}$ percentile of its category, with 2.1 (quartile 1) and a citation percentage of $65 \%$, ranking $43^{\text {rd }}$ among 556 journals in the general medicine category ( Fig. 4); it is the eighth journal of the Elsevier publishing house, only behind Lancet (10.28), Lancet Global Health (4.51), Mayo Clinic Proceedings (4.03), Patient Education and Counseling (3), Sleep Medicine (2.78), Medical Clinics of North America (2.37) and Advances in Medical Sciences (2.1).

In September 2017, the journal received the Scimago-Conacyt award, in recognition as the first Mexican scientific journal classified in quartile 1 (Fig. 5).

Fifty years after its inception, the journal faces new challenges. On one hand, the global trend towards open science forces us to rethink the contract model with Elsevier publishing house in order for the journal to appear in the open access modality, which will also allow greater penetration and visibility in the world scientific community. In second place, the attraction of manuscripts of higher scientific quality, and participation of internationally renowned reviewers, who provide the authors with constructive feedback in order for them to improve 


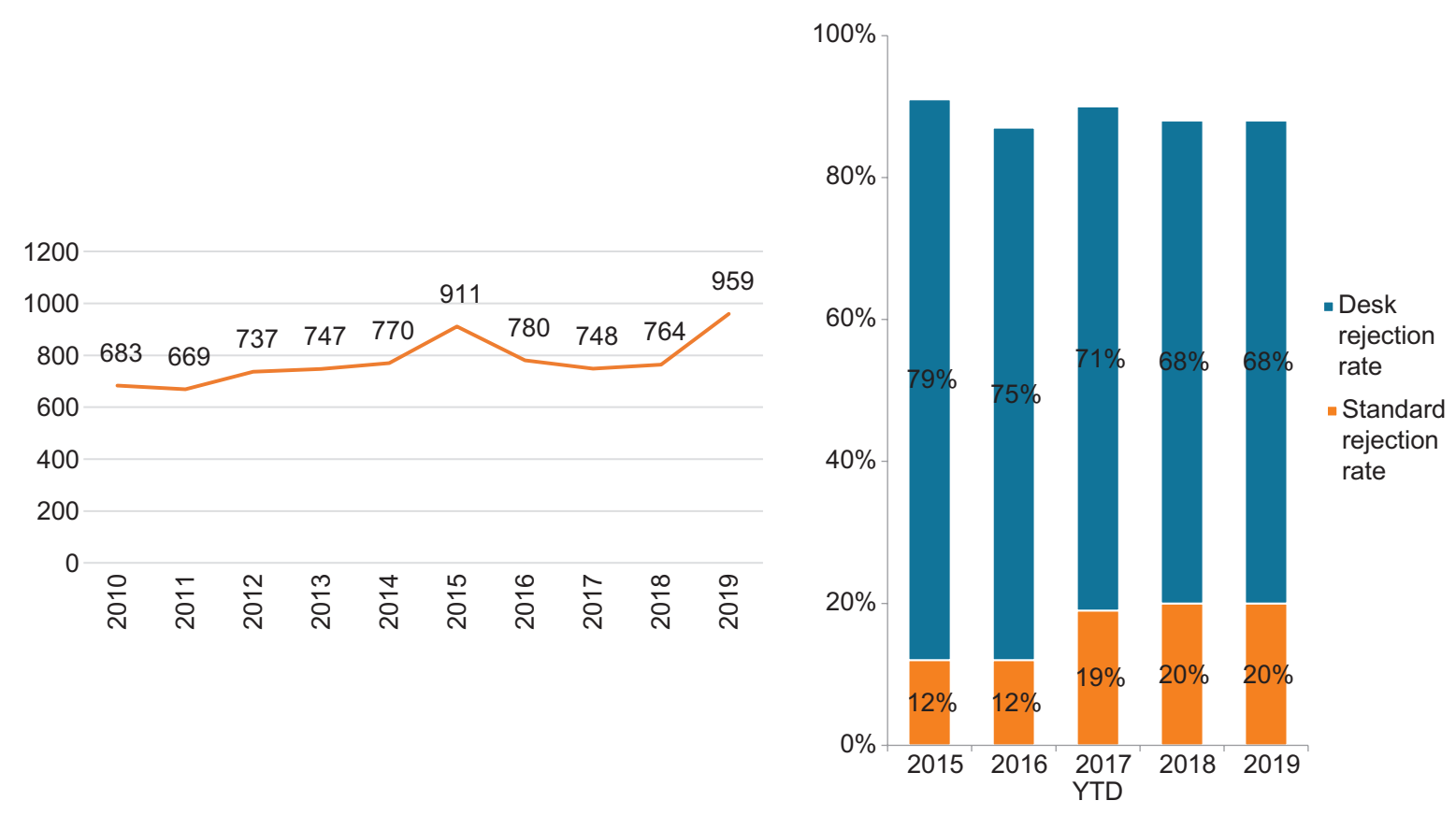

Figure 2. Received manuscripts and rejection rate per year, Archives of Medical Research.

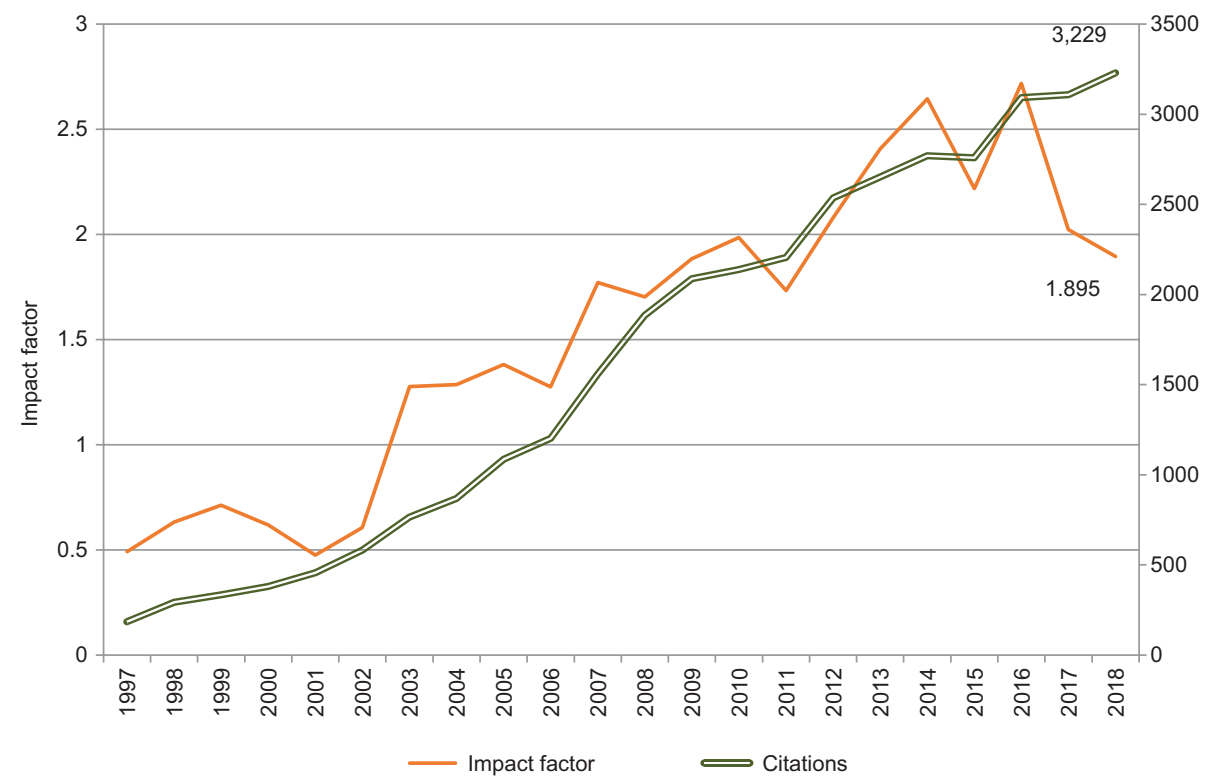

Figure 3. Archives of Medical Research impact factor (Journal Citation Reports) and number of citations per year.

their manuscripts. The third challenge will be to continuously modernize and improve administrative processes and decrease publication times in order to be internationally more competitive and, finally, continuous training of the editorial team and timely training of replacement staff.
As it can be observed in this brief review, organization, growth and development of a scientific journal in a developing country requires mid- and long-term planning, continuous investment and institutional support, as well as the commitment and passion of all those involved in the process. 


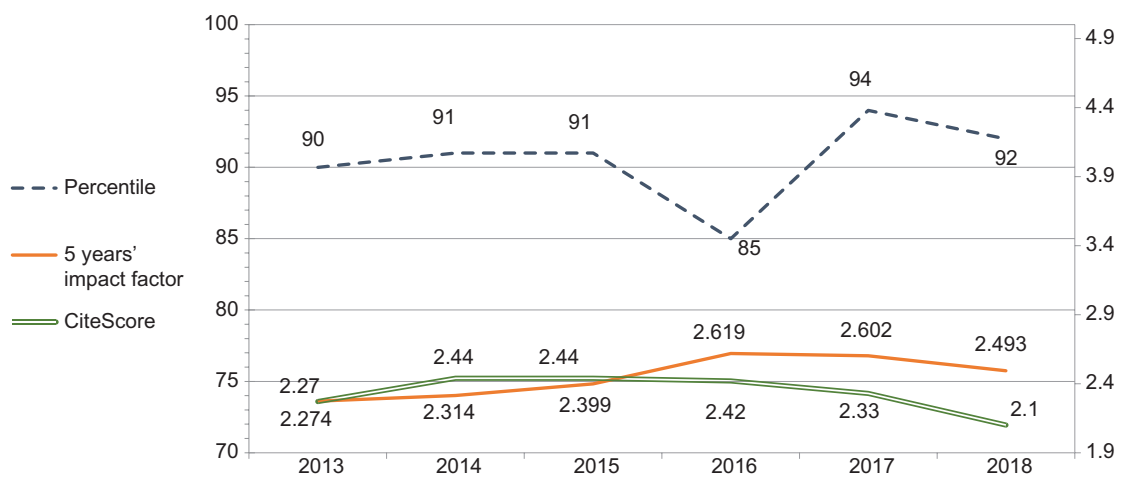

Figure 4. Scopus CiteScore, Archives of Medical Research.

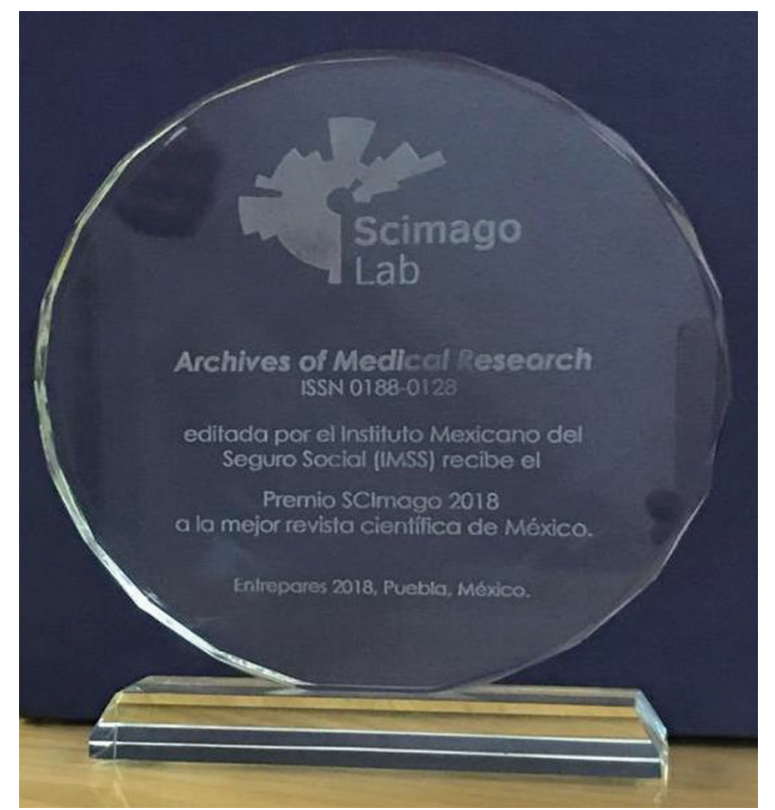

Figure 5. Scimago-Conacyt recognition awarded to Archives of Medical Research.

\section{Revista de Investigación Clínica-Clinical and Translational Investigation ${ }^{1 *}$}

\section{Alfredo ulloa-aguirre, moisés selman-lama, LUIS OÑATE-OÑATE}

The first issue of Revista de Investigación Clínica was released in 1948, two years after the opening of the Hospital for Nutritional Diseases (currently, National Institute of Medical Sciences and Nutrition "Salvador Zubirán”), founded by Dr. Salvador Zubirán Anchondo. Its first editor and founder was Dr. José Báez Villaseñor

1 *Dedicated to Dr. José Báez Villaseñor, great friend, extraordinary physician and founder of Revista de Investigación Clínica.
(1948-1970), who was followed by Dr. Rubén Lisker (1971-1998, with Dr. Enrique Wolpert [1974-1988] and subsequently chemist Alvar Loria [1989-1998] as co-editors) and Dr. Gerardo Gamba (1999-2014). Since 2015, the editor-in-chief is Dr. Alfredo Ulloa-Aguirre, with Dr. Moisés Selman and Dr. Luis Oñate as co-editors. Since its founding, the journal has been continuously published, initially quarterly and, since 1993, bimonthly.

Revista de Investigación Clínica has evolved throughout four periods, with different particular characteristics imprinted by its different editors-in-chief. Initially, during its first period, most published articles (nearly $90 \%$ ) came from Hospital for Nutritional Diseases authors. In the second, as the journal increasingly positioned itself among the community of national clinical researchers as a respectable publication in terms of the quality of its articles, the contribution of authors of its founding hospital was reduced by half, with the influx of works by researchers from other institutions, most of them national. The Science Citation Index, a database that is currently part of the Web of Science, which belongs to the Clarivate Analytics company, was the origin of the impact factor or index, as a reflection of citations and, consequently, of the impact of articles published in the different scientific journals included in this database; this impact factor is published annually by Journal Citation Reports, which is integrated to the Web of Science platform. It was precisely during this second period that RIC obtained its first impact factor, which until 2018 ranged approximately between 0.25 and 0.5 (Fig. 6). By the end of this period, the journal became access-free through its online version, without the publication of the printed version being interrupted.

The third period had some remarkable characteristics:

- Greater emphasis was given to articles that were of interest to national readers by predominantly publishing works of local impact that could 
Gaceta Médica de México. 2020;156

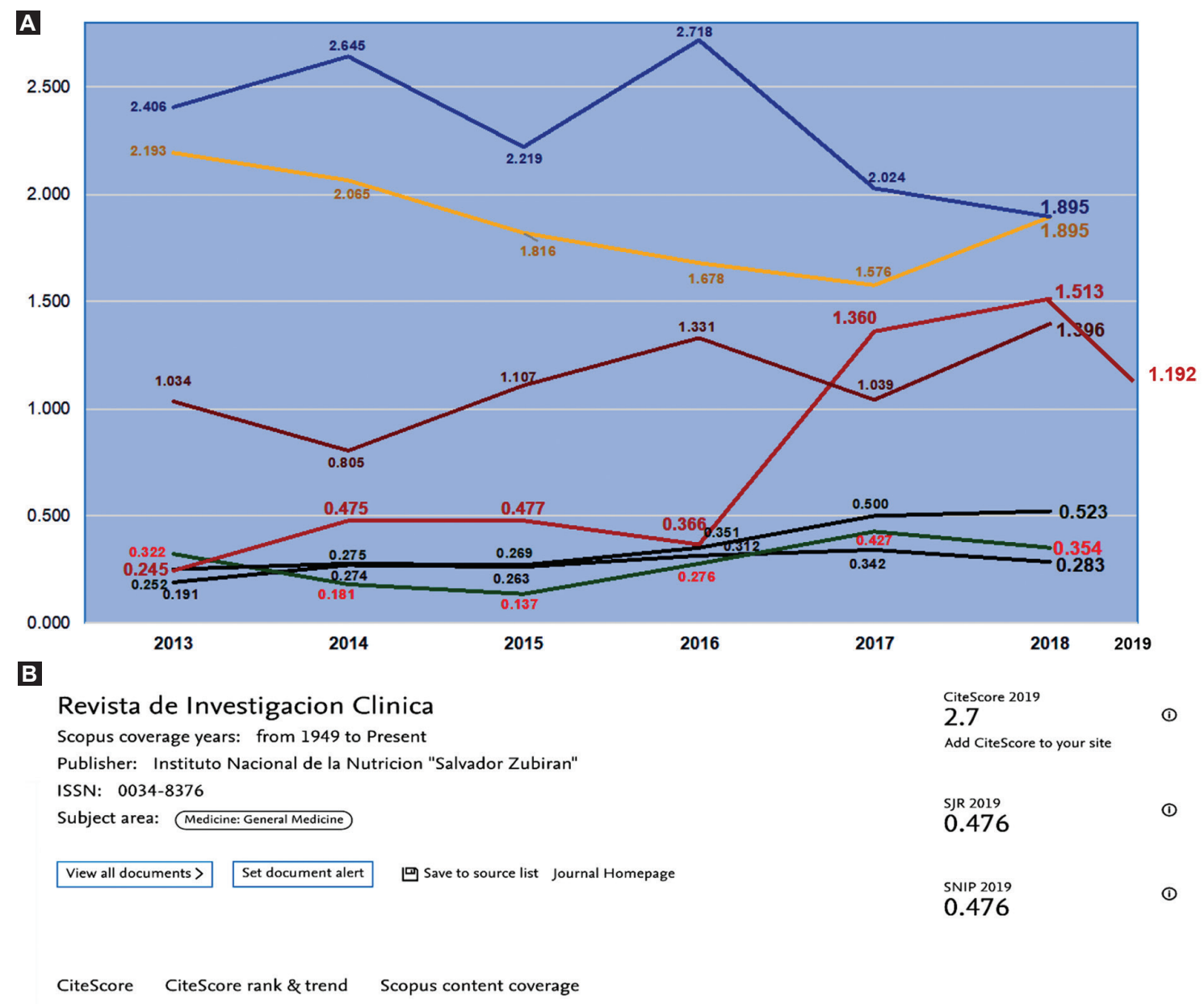

i Improved CiteScore methodology
CiteScore 2019 counts the citations received in 2016-2019 to articles, reviews, conference papers, book chapters and data
papers published in 2016-2019, and divides this by the number of publications published in 2016-2019. Learn more >

\begin{tabular}{|l|l} 
CiteScore 2019 & CiteScoreTracker 2020 (1) \\
$2.7=\frac{437 \text { Citations } 2016-2019}{162 \text { Documents } 2016-2019}$ & $\mathbf{1 . 5}=\frac{195 \text { Citations to date }}{129 \text { Documents to date }}$ \\
Calculated on 06 May, 2020 & Last updated on 10 June, 2020. Updated monthly
\end{tabular}

CiteScore rank 2019 (1)

\begin{tabular}{lrl} 
Category & Rank & Percentile \\
\hline Medicine & & \\
$L$ General Medicine & $\# 87 / 529$ & 83rd
\end{tabular}

Figure 6. Revista de Investigación Clínica-Clinical and Translational Investigation impact factor and CiteScore (Elsevier) until 2019. A) Impact factor trajectory according to Journal Citation Reports (Web of Science). Note the rapid increase starting on 2017, from 0.245 in 2013 to 1.513 in 2018. B) CiteScore is another measure of the impact of an academic journal; it shows an annual average of citations of recent articles (20162019) published in the journal. CiteScore was launched in 2016 by Elsevier publishing house, as an alternative to the impact factor. Impact factor and CiteScore values are similar, but the latter is based on citations recorded in the Scopus database during the previous three years, instead of two or five years considered by Journal Citations Reports.

potentially influence diagnostic or therapeutic behaviors in Mexico, as well as the training of physicians. The printed version was distributed in libraries of almost all Latin American countries.
- The journal was opened to contributions of resident physicians, in order for them to be able to get started on the preparation and writing of articles, mainly on clinical research. 
- In 2008, it became the journal of the National Health Institutes of Mexico, in order to increase the contributions of physicians and researchers from other institutes.

- The impact factor remained at around 0.45, which unfortunately was insufficient for the journal to be taken into account by the National System of Researchers (Fig. 1A).

Revista de Investigación Clínica fourth and current period began in 2015. The purpose of the change was for the Coordinating Commission of the National Health Institutes of the Ministry of Health to provide both financial and dissemination support to the journal. Our program was fundamentally based on internationalization of the journal with the purpose to increase its impact factor and this way making it more attractive to national and international researchers. Moreover, this would allow the journal to adjust to National System of Researchers criteria to be considered on its list of scientific journals and to be taken into account for the evaluation of articles published by national researchers. For these purposes, the following modifications were made:

- The name of the journal was changed to Revista de Investigación Clínica-Clinical and Translational Investigation, in order to give higher priority to contributions that are not only original but also translational medicine-oriented.

- The publishing company was changed, with this responsibility been given to the Permanyer publishing house (Barcelona, Spain).

- The editorial board was substantially modified and the type of articles was broadened (full-length reviews, short reviews, brief communications, research letters, original articles and letters to the editor).

- The language of the content was changed from being bilingual (English or Spanish) to being entirely in English, including its online platform (www.clinicalandtranslationalinvestigation.com) for the deposit of articles, communication between editors, assignment of reviewers, etc.

- Printing on paper was limited, giving priority to online, open access publication.

- The number of articles included in each issue was considerably reduced (almost by $50 \%$ ), with six to nine articles per issue being published, and peer review being programmed as expeditiously as possible (maximum 30 days), with an average time of 60 days from the reception of an article to its acceptance.
- The cover was modified to make it more attractive to readers (Fig. 7) and pharmaceutical industry advertisements were completely eliminated.

With these changes, the impact factor increased to 1.360 in only three years (2015-2017) and, in the 20182019 period, to 1.513 (Fig. 6), to remain only below Annals of Hepatology and Archives of Medical Research among the Mexican journals. In 2019, the impact factor decreased to 1.192 , a fact that was importantly influenced by the withdrawal of financial, dissemination and bibliographic support from the Coordinating Commission of the National Health Institutes since January of that year. However, in Scopus CiteScore, Revista de Investigación Clínica index increased from 1.29 to 2.7 (CiteScore considers the citations of articles and reviews received during 2016-2019 and divides them by the number of documents published during the same period; in the case of Revista de Investigación Clínica, the numerator was 437 and the denominator was 162) (Fig. 6).

In addition to the decrease in the number of articles published in each issue, another factor that has contributed to the increase in the impact factor and CiteScore has been the periodic publication of thematic issues (five between 2016 and 2019 and two additional scheduled for 2020, including one on COVID-19, number 3, May-June). The number of users during 2018 and 2019 was 19,225 and 25,155, respectively; by December 31,2019 , the number of visits to the site for that year was 61,047, mostly from Mexico ( 30\%), the United States ( 14\%), China ( 7\%), Brazil and Spain ( $5 \%$ each), among others. In 2019, 229 articles were received, out of which $63.3 \%$ were rejected for publication. Table 1 shows some of Revista de Investigación Clínica most read articles until 2019. For 2018, it ranked $102^{\text {nd }}\left(81^{\text {st }}\right.$ percentile) among the 549 general medicine journals considered by Scopus-Elsevier CiteScore. Revista de Investigación Clínica (ISSN 0034-8376 and ISSN 2564-8896) is currently indexed by Medline (Pubmed), Science Citation Index Expanded (Joint Committee on Intercollegiate Examinations), Scopus, SCRMCYT-Conacyt, Latindex (Catalog and Directory), Artemisa, Imbiomed and MIAR (Information Matrix for Journal Analysis, University of Barcelona, Spain).

\section{Gaceta Médica de México, the strength of the National Academy of Medicine of Mexico}

\section{Alejandro tREVIÑO-BECERRA}

If I was to say that Gaceta Médica de México, founded in 1864, is the oldest Mexican journal in our 


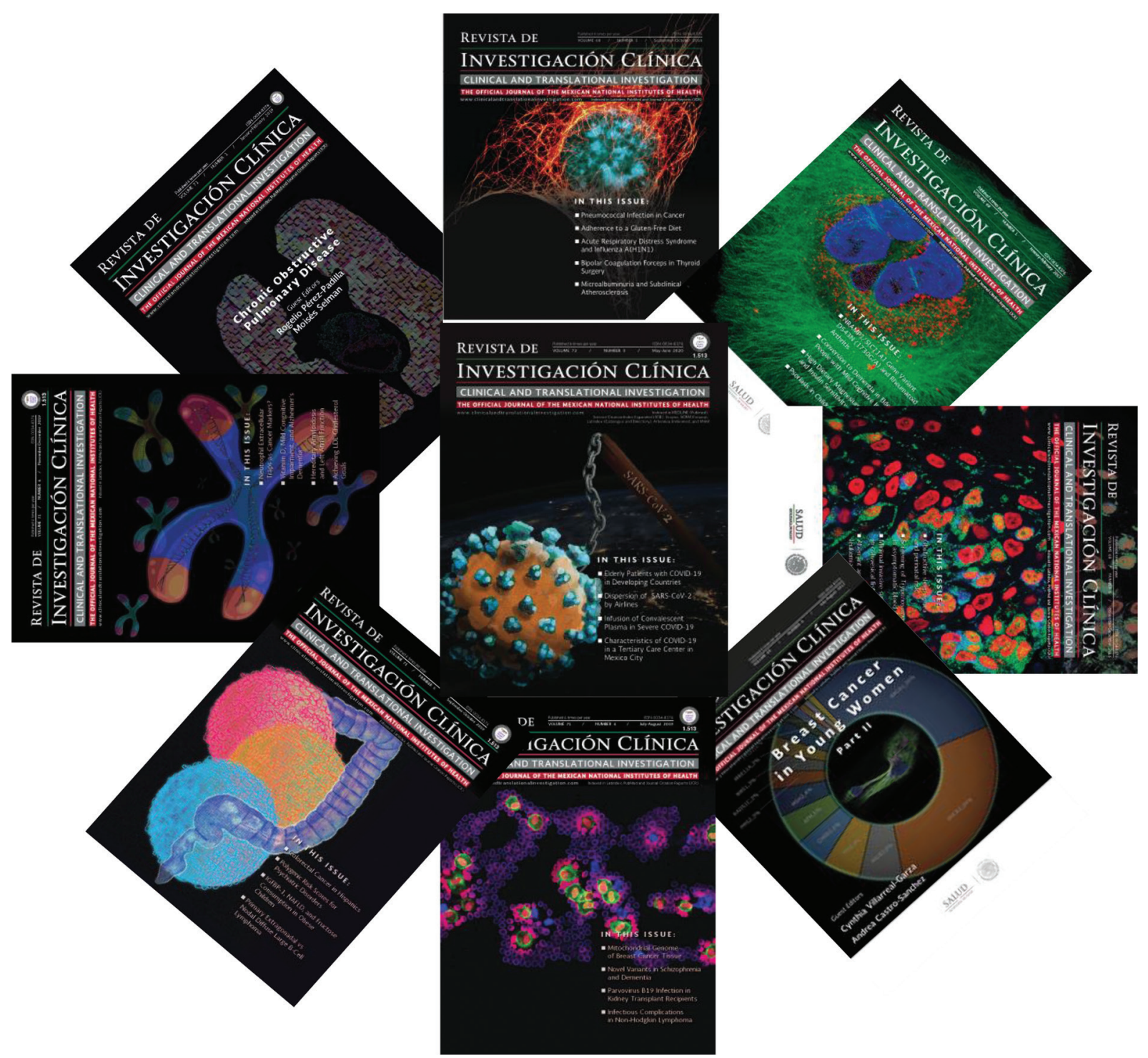

Figure 7. Some Revista de Investigación Clínica-Clinical and Translational Investigation covers, published between 2015 and 2020.

country, I would not be untrue, but I would be if I said that its publication has been uninterrupted, since, in 1917, it stopped being published to resume in 1919 , as referred by historian Martha Eugenia Rodríguez Pérez. One century later, in 2019, the journal stopped being published in print, although the Permanyer publishing house generously prints three copies of each issue in order to keep the entire collection in the library and in historical archives.

In more than one and a half century, before us there were 29 editors, and if associate co-editors are accounted for, we will add another 59 , almost all of them academicians. The three editors with the longest tenure have been Miguel Jiménez, Luis Benítez Bribiesca and Don Silvestre Frenk, whom we physically lost this year and who was editor from 1967 to 1984, most these years as sole editor. Another great loss was that of my friend and mentor, Dr. Francisco Olvera Esnaurrízar, Gaceta Médica de México associate editor in the 1960-1961 period, who later started the development of Revista Mexicana del Instituto Mexicano del Seguro Social.

I collaborated with two proficient editors: with Dr. Francisco Pérez del Rincón I assisted as associate editor for two years, and later with the coordinator of this symposium, Dr. Alfredo Ulloa Aguirre (with Dr. Fernando Larrea as co-editor); I collaborated as treasurer when the president of the National Academy of Medicine in turn, Dr. Emilio García Procel, formed an administrative committee to support the editors. 
Table 1. Articles published in Revista de Investigación Clínica-Clinical Research and Translational Investigation that were most read during the 2016-2019 period

\begin{tabular}{|l|l|l}
\hline Article ID & Tittile & Number of readings \\
\hline 187 & Familial combined hyperlipidemia: current knowledge, perspectives, and controversies & 844 \\
\hline 171 & $\begin{array}{l}\text { Nutritional assessment tools for the identification of malnutrition and nutritional risk associated } \\
\text { with cancer treatment }\end{array}$ & 739 \\
\hline 198 & Smoking cessation treatments: current psychological and pharmacological options & 592 \\
\hline 140 & $\begin{array}{l}\text { Practical approach to the evaluation and management of rheumatoid arthritis-interstitial lung } \\
\text { disease on its proven and hypothetical mechanisms }\end{array}$ & 514 \\
\hline 73 & Biology of healthy aging and longevity & 453 \\
\hline 174 & Use of functional foods and oral supplements as adjuvants in cancer treatment & 347 \\
\hline 83 & The role of immunosenescence in the development of age-related diseases & 330 \\
\hline 213 & Frailty and sarcopenia: the new geriatric giants & 329 \\
\hline 201 & I. The role of research ethics committees in observational studies: epidemiological registries, \\
\hline
\end{tabular}

In the decade of 1960, two temporary modalities deserve to be mentioned: on one hand, the participation of up to six academicians in the editorial function, who were divided for three to four issues of a given year; on the other hand, the staggered renewal of the editorial group, where the co-editor was promoted to editor in a new board of directors.

In 2017, I implemented the idea of resuming administrative and technical support, for which we invited Dr. Francisco Espinosa Larrañaga to serve as executive editor based on his experience. I believe that the participation of an executive editor is required with payment of fees for the hours of work he must dedicate to each issue and constant work with the editor and co-editors.

Currently, co-editors are Miguel López Cruz, a national researcher with international recognition, and Martha Eugenia Rodríguez Pérez, a renowned historian of medicine and, by the way, the first woman to belong to Gaceta Médica de México body of editors; Alma Morales works as assistant, and with her we have formed a friendly, plural, hard-working and successful team. We succeeded doctors Alberto Lifshitz, José Halabe and Manuel Ramiro. We also agree our projects with engineer Víctor Torrecillas, our official translator, Elizabeth Gallardo, Mr. Ricardo Permanyer himself, commercial director Frank García and Gabriela Ramírez. In addition, we included Miguel Ángel Vázquez as digital systems executive and accountants Paola Valencia and Gabriela Nava, for accounting support.
In my experience, three types of relationship can be established between the Academy's governing body and the editorial group: dependency, independence, and co-responsibility, with the latter being the most useful, but also the most difficult to achieve.

Regarding Gaceta facts and figures, we should highlight that we are up to date in terms of acceptance or rejection of works. In three and a half years, 1,558 works were received (from January 2017 to June 1, 2020). To facilitate the work and follow-up, operational guidelines were developed, one for acceptance or rejection and another to filter and help the review and reviewers identification.

Gaceta Médica de México greatest weakness was reviewers' poor and late response; in recent months, this has improved due to increased communication and recognition of reviewers; however, increasing the number of reviewers is recommendable, as well as for them to perform their task expeditiously. I also believe that the term "reviewer" can be changed, since it scares away peers or else encourages them to thoroughly analyze the work. Furthermore, if the review is by peers, sometimes a good manuscript prepared by young doctors reaches an academician's desk and an odd circumstance is established, i.e., an apprentice before an expert or teacher.

We believe that in these almost four years, Gaceta Médica de México has had advances not only with the cover change. In 2017, we published all six regular 
issues, an extraordinary issue only in electronic version with 38 lagged articles, one supplement with academicians' admission works for the corresponding year, and another sponsored supplement, i.e., nine issues in the first year. With two supplements of a total of 10 that are in preparation for the second semester, a total of two supplements will be published, and with the income from sponsors, paying the translator for the last issues of this year is planned.

The members of the board and the editorial committee participate more and have greater visibility, and communication has been established with them for formal matters of the journal; with the members of the committee, to encourage them and thank them for their participation. We withdrew sections in order to give uniformity to the content: editorial, original articles, review topics, brief communications, letters to the editor and a small section on the life of the Academy. We do not always have a symposium to publish those presented in the Academy sessions.

This drives us to reflect on what type journal should Gaceta be: for researchers and to try to increase the impact factor, the most recent of 0.283 , and trying a bibliometric study to have other quality parameters, such as CiteScore (0.342) of Scimago Journal \& Country Rank and $\mathrm{H}$ index (17). Few academicians publish in Gaceta; if they did, the impact factor would rise.

The members of the editorial board, the next boards of directors and academicians themselves must specify and define: what type journal should Gaceta Médica de México be? Although I would leave it just as it is: a quality Mexican journal that is sought after, printed in Spanish and online translated into English, open to all areas of medical knowledge, updated, useful, read, indexed, interesting and international. Hence, as of this year, Gaceta Médica de México carries the subtitle Medicina Contemporánea (Contemporary Medicine). It will continue publishing the best works it receives. An office specialized in translations commented that the journal is highly complex and difficult because its content is extremely broad and the subject matter varies from issue to issue.

I cannot omit mentioning that, in these last two years, Gaceta Médica de México has been affected by the budget cuts and, in 2019, the printed form was suppressed. In this regard, two editors issued significant opinions. Dr. Silvestre Frenk sent an email expressing his thoughts:

It seems to me that stepping into the digital era is an inevitable consequence of current times, even for Gaceta Médica de México. Thus, I have nothing else to say but: that's the way things are.

Dr. Francisco Olvera Esnaurrizar expressed that the printed journal could not disappear and that each academician could be asked for a small contribution or a patron be found to support it.

For the same economic reasons, this year we were asked by the board of directors to ask potential authors to submit the electronic version of their works in English, in order for not to pay for the translation in the "scientificist" and "efficientist" interest of Gaceta Médica de México.

On the other hand, in this year's issue number 4, 10 works on COVID-19 were published, out of more than 40 that were received by the editorial board between February and May of current year, which, added to those published in numbers 2, 3 and 5 , yields a total of 25 papers on this topic. This indicates the position currently occupied by Gaceta.

One reflection: the building that harbors the National Academy of Medicine of Mexico, is the headquarters of three of the journals that participate in this symposium.

- Archives of Medical Research.

- Cirugía y Cirujanos.

- Gaceta Médica de México.

And also of other two that are not participating in the symposium, Revista Médica del Instituto Mexicano del Seguro Social and Revista de Enfermería del Instituto Mexicano del Seguro Social.

All three participant journals have similarities and differences, but are facing, among other things, economic problems; if we were entrepreneurs we would try to reduce weaknesses and take advantage of opportunities to guarantee our editions in the short and medium term, in a sort of consortium.

On the other hand, there are many quality works that are not accepted, a situation that also occurs in Cirugía y Cirujanos, which shows that a new, simpler, more frequent medical journal is required, with wider circulation, away from bibliometrics, self-financing and useful for our doctors and readers.

Finally, from the documents published on "the world after the COVID-19 pandemic", I would like to quote the following concept:

People need to trust public authorities, science and the media. The National Academy of Medicine is an authority on Mexican medicine, and its Gaceta, with its scientific medical publications, turns it in an extraordinary and accessible means of medical communication. 
Gaceta has been current in three centuries, hence its strength upheld by dedication, altruism and medical intellectual production. I hope the journal continues to be the biggest strength of the National Academy of Medicine of Mexico and that it withstands external and internal adversities.

\section{Salud Pública de México}

\section{Carlos oropeza-abúndez}

Salud Pública de México was published for the first time in 1959, as a dissemination body of former Ministry of Public Health and Assistance, the governing institution of the Mexican State in the field of health. It was born with the purpose to address issues not only concerning general medicine, but also epidemiology, sanitation, administration and health legislation, among others, as well as to disseminate notes on public health at the national and international level. ${ }^{5}$ It should be noted, however, that the journal is the product of an historical transformation and amalgamation of different official informative bodies on the subject. The main background in this sense is Boletín del Consejo Superior de Salubridad (which was launched in 1880), considered the first Mexican periodical aimed at addressing public health issues. ${ }^{5,6}$ Later, other publications followed, according to developments shown by the different governmental instances created to care for population health.

In the mid-1960s, already established as a journal, Salud Pública de México absorbed Boletín Epidemiológico, first published in 1937 as a means of dissemination by the Tropical Diseases Epidemiology and Prophylaxis General Office. Some time later, in 1977, it did the same with Revista del Instituto de Salubridad $y$ Enfermedades Tropicales, and as a result of this, it broadened its scope, not only in epidemiological surveillance and as a body for the Ministry of Public Health and Assistance activities dissemination, but it began to acquire a scientific nuance. ${ }^{5}$

However, there are three facts that ended up conferring Salud Pública de México an academic nature: the first of them has to do with the fact that, in 1979, the Ministry of Public Health and Assistance informative notes started being published in a specific institutional bulletin and that the dissemination of the annual epidemiological report remained under the responsibility of Boletín de la Dirección General de Epidemiología. The second is related to the creation of the Public Health Research Center, which resulted in, that in 1985, the journal, then in charge of the School of Public Health of Mexico, included a section edited by said center among its contents. The third one has to do with the creation, in 1987, of the National Institute of Public Health; as a result, Salud Pública de México ceased to fulfill its role as official body of the Ministry of Health and was left under the conduction of the Institute. ${ }^{1}$ The latter event marked the preparation of a new era for the journal, defined by the strengthening of its scientific content through the expansion of its editorial committee, inclusion of a larger number of original research works, formalization of the peer review process and adherence to international editorial standards such as the Uniform requirements for manuscripts submitted to biomedical journals. ${ }^{7}$

As of 1988, the journal has been published following the guidelines of a new era, and its incorporation to the indexes and databases with the greatest international presence is expanding. Being already included in some of them, in 1993, for example, it managed to be admitted to the Social and Behavioral Sciences version of Current Contents. The following year, it was certified by the Index of Mexican Journals of Scientific and Technological Research of the National Council of Science and Technology (Conacyt), and in 1997, by express invitation of the Latin American Center for Information on Health Sciences (BIREME) of the Pan American Health Organization-World Health Organization, the journal was incorporated to the SciELO Public Health initiative, which it is part of to this day (Table 2).

The honors obtained by Salud Pública de México are diverse: in 2014, Conacyt awarded a recognition to its editors for their work in charge of the journal. One year later, this same body granted the publication an award highlighting it as a "highly ranked multidisciplinary Mexican journal", and in 2017, it was classified as "the best scientific journal of Mexico" in all areas of knowledge. ${ }^{8}$

The impact factor, created by the Institute for Scientific Information in 1975 and currently published by the Clarivate Analytics company, is also a reason for attention for Salud Pública de México editorial body. Since the journal's acceptance in the Social Sciences Citation Index, the score it has obtained in this indicator has been on the rise for more than 20 years (Fig. 8).

To remain current in the field of scientific communication, Salud Pública de México, like the main international journals, monitors and updates itself in 
Table 2. Indexes and databases Salud Pública de México is enrolled in, 2020

Abstracts on Hygiene and Communicable Diseases

Biological Abstracts

BIOSIS Previews

Current Contents/Social and Behavioral Sciences

Directory of Open Access Journals (DOAJ)

EMBASE/Excerpta Medica

Essential Science Indicators

Global Health/CAB Abstracts

Índice de Revistas de Educación Superior e Investigación Educativa (IRESIE)

Latindex

LILACS

MedicLatina

Periódica

RedALyC

SciELO Citation Index

Scientific Electronic Library Online (SciELO)

Scopus (Elsevier)

Sistema de Clasificación de Revistas Mexicanas de Ciencia y Tecnología CONACYT

Social Sciences Citation Index (Web of Science Core Collection (Clarivate)

accordance with the best editorial practices: operation through an online submission and management system (Open Journal Systems, open source), use of digital identifiers (DOI) and interoperability versions (XML), adoption of Creative Commons open access licenses, timely dissemination through ahead of print publication and adherence to initiatives such as San Francisco Declaration on Research Assessment (DORA) and Initiative for Open Citations.

As for its content, which is fully digitized and with open access since the first issue of 1959, Salud Pública de México prioritizes the results of research that concern population health in the world, while strengthening the analysis of relevant health problems in Mexico:9,10 chronic diseases, injuries, mental health, health system reform, aspects related to medical sociology and anthropology, health economics, hospital administration and definition of health policies. The most advanced instrumental developments in the field of epidemiology are privileged, including works of excellence in the areas of nutrition, reproductive health and environmental health. The biological bases of public health are present through the analysis of issues related to experimental research in the fields of bacterial resistance, immunity and development of vaccines, among others. Emerging and re-emerging disease trends are also a permanent subject on the journal's pages.

The publication and expeditious visibility of results of research on the great threats that currently harm the health of the population in the planet (such as the COVID-19 pandemic, caused by the SARS-CoV-2 virus) are aspects of high priority for Salud Pública de México. ${ }^{11,12}$ The search for new routes and paradigms to face this type of circumstances is, without a doubt, one of the great challenges all scientific journals in the region must respond to.

With editorial independence and without the tutelage or participation of commercial consortia, Salud Pública de México ratifies that, for a publication of excellence to contribute to improving the health conditions of the population, open access to knowledge as a public good and adherence to scientific communication ethics have to continue to be the pillars of its identity and editorial policy.

\section{Cirugía y Cirujanos}

\section{Sergio sobrino-cossío AND PEDRo GUTIÉRREZ-CASTRELLÓN}

Medical updating requires the search for knowledge. Prevention strategies, epidemiological behavior of diseases, early diagnosis, timely treatment, management of complications, and health decision-making are supported by scientific evidence. ${ }^{13}$

In a globalized world, we need to have access to the main specialized medical journals. There are specialized journals in one area, such as, for example, oncology, cardiology, hematology, etc., and others that cover many. Ultimately, the challenge for all of them is the generation of high-quality knowledge (Iogos), easy understandability, acceptance (pathos) and credibility (ethos).

Since its creation in 1933, Cirugía y Cirujanos has highly efficiently carried out its relevant mission of being the scientific dissemination body of the Mexican Academy of Surgery, a Federal Government 


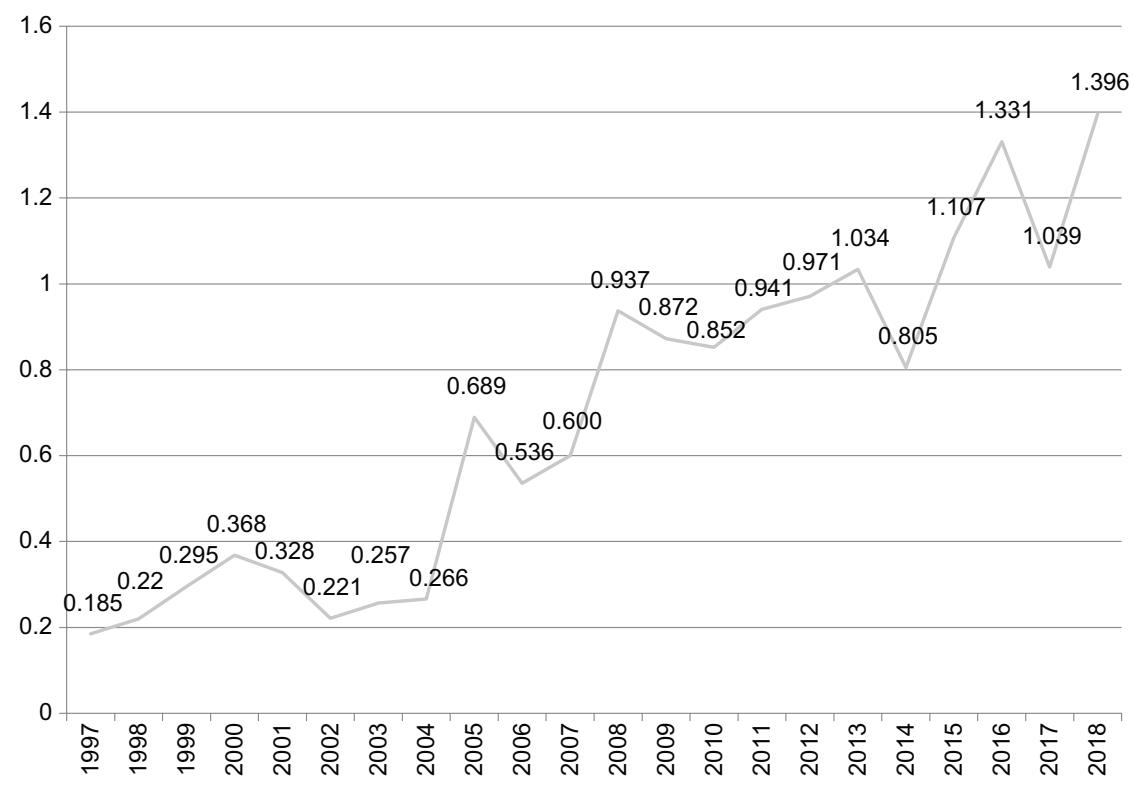

Figure 8. Salud Pública de México impact factor, 1997-2018.

consultative body in matters of health and social policy, and advisor to the General Council of Health of Mexico. The journal appears in various bibliographic indexes such as Index Medicus, Excerpta Medica and Latin American Index of Scientific Journals, among others.

Cirugía y Cirujanos goal is to publish original works from the broad field of medicine, as well as to provide updated and relevant information for the national health area. Our journal is bilingual (Spanish/English), bimonthly, open access, and undergoes a rigorous peer review process. Its content includes editorials, original articles, case reports, review articles (general interest) and letters to the editor.

Cirugía y Cirujanos is governed by editorial ethics, which includes a code of good practice, protection of human and animal subjects, confidentiality, privacy, financing, authorship (Uniform requirements for manuscripts submitted to biomedical journals) and declaration of conflict of interests.

Credibility of journals relies on:

- Impact factor, which refers to the number of times an average article has been cited in a journal for a given year, divided by the total number of articles published in the previous two years.

- A rigorous peer review process (content experts) whereby whether a manuscript is feasible, interesting, novel, with ethical and relevant methodology is evaluated.
The peer review process includes several steps:

1. Review by the editorial office.

2. Review (editor-in-chief).

3. Assignment of a responsible editor.

4. Invitation of reviewers.

5. Peer review.

6. Evaluation of review results by the journal.

7. Communication of the final decision to the author (accepted/rejected)

8. Double grammar, style and references review in the final version (publishing house).

9. Mock-up tests of the article prior to publication (author final authorization)..$^{14,15}$

Table 3 shows Cirugía y Cirujanos impact factor behavior in recent years. A high factor will indicate that the publication is highly influential in the medical community; it is an indicator of the impact of the manuscript of a specific author. A journal with an impact factor of three will mean, on average, that articles published in the last two years have been cited three times.

The performance of an investigation and the monitoring of scientific trends can be evaluated through quantitative analysis.

The higher the impact factor of a journal, the lower the acceptance percentage of a manuscript submitted for publication (in Lancet it is only $5 \%$ ). Impact factor was 42.315, 39.207, 30.0, 16.3, and 16.104 for Nature (2014), Lancet (2013), JAMA, British Medical Journal (2014) and Annals of Internal Medicine (2014), 
respectively. However, the number of citations does not reflect the methodological quality.

A huge task for publishers in the face of the considerable flood of articles ruled by fashion is to detect scientific fraud and duplication of articles. Physicist Alan Sokal, after publishing a sophisticated article in 1996 (Transgressing the boundaries towards a transformative hermeneutics of quantum gravity), exposed the lack of rigor and evaluation of the body of editors of the prestigious journal Social Text. ${ }^{16}$ Sokal wanted to confirm that a journal on humanities "will publish an article full of nonsense, as long as: a) it sounds good; and b) it supports the publishers' ideological prejudices (against empirical sciences)". He concluded that objectivity is a social convention after informing on his parody.

In 2002, another scandal occurred. The Bogdanov brothers, to avoid peer review, published absurd and nonsensical theories in prestigious scientific journals, which later were qualified as pseudoscience. ${ }^{17}$ Another scientific fraud in the Nature and Science journals involved physicist Jan Hendrik Schön in 2002. ${ }^{18}$ Another one was the dispute over the paternity of HIV isolation between Montagnier, who published his discovery in Science, and Gallo. ${ }^{19}$

Recently, we had the big fake data scandal against hydroxychloroquine that involved the New England Journal of Medicine and the Lancet through a shell company, with both journals having to retract their statements about the risks of the drug, related to serious heart problems and to an increased risk of death in patients with COVID-19.20

For all these reasons, our body of editors has started a reengineering of processes in the journal, among which implementation of an evaluation process for publication proposals adhering to current needs and an invitation to experts in research methodology and evidence-based medicine to become part of the reviewers' staff and the development of systematic reviews and clinical practice guidelines stand out.

\section{Salud Mental}

\section{HÉCTOR ESQUIVIAS-ZAVALA}

Salud Mental is Instituto Nacional de Psiquiaría "Ramón de la Fuente Muñiz" official publication, which has been published since August 1977. It has been appearing uninterruptedly since its foundation and has a bimonthly periodicity. In accordance with the best practices for publishing in scientific journals, the received manuscripts are initially screened by an internal review committee; approved documents are subsequently peer reviewed in a double-blind process by experts on different subjects. The journal publishes monothematic issues on relevant topics for the scientific community such as obesity and mental health, addictions, and soon it will publish monothematic fascicles on the impact of COVID-19 on mental health and occupational mental health.

Salud Mental is indexed in Web of Science's Social Science Citation Index, Scopus, Academic Search Premier, Journal Citation Report, SciELO, PsycINFO, IMBIOMED, RedALyC, LILACS, BIREME, EBSCO, DIALNET, MIAR, Latindex, QUALIS and Mexican Journals of Science and Technology Classification System (Conacyt).

Since 1977, Salud Mental has sought to answer to mental health researchers editorial needs. Its line of action considers four essential criteria: continuing education, updating, information and dissemination of the works of both institutional and external researchers with a multidisciplinary approach. More than three decades after its founding, it has become a forum for national and international psychiatry, neuroscience and psychology researchers (Fig. 9). The journal is also an international scientific communication channel and is indexed in recognized national and international indexes.

In 2012, implementation of an electronic editorial assistant favored an exponential increase in the number of papers submitted to the journal. This, together with the editorial team reduced operational staff, generated the need to meet this challenge without neglecting the quality of its contents. At that time, a situational analysis of Salud Mental drove to the inescapable need to strengthen the editorial team with the integration of new members who would coordinate editorial work and more rigorously assess the quality of received manuscripts. Thus, new processes were implemented in order to optimize available human and economic resources. An internal evaluation committee was created, which exhaustively reviews each manuscript prior to being evaluated by external peers. The methodological requirements evaluated by the committee guarantee the impact of the publication.

Current rejection rate of the publication is 85 to 90 $\%$ and all peer-reviewed manuscripts receive feedback. Implementation of this process has enabled 
Documents published per year

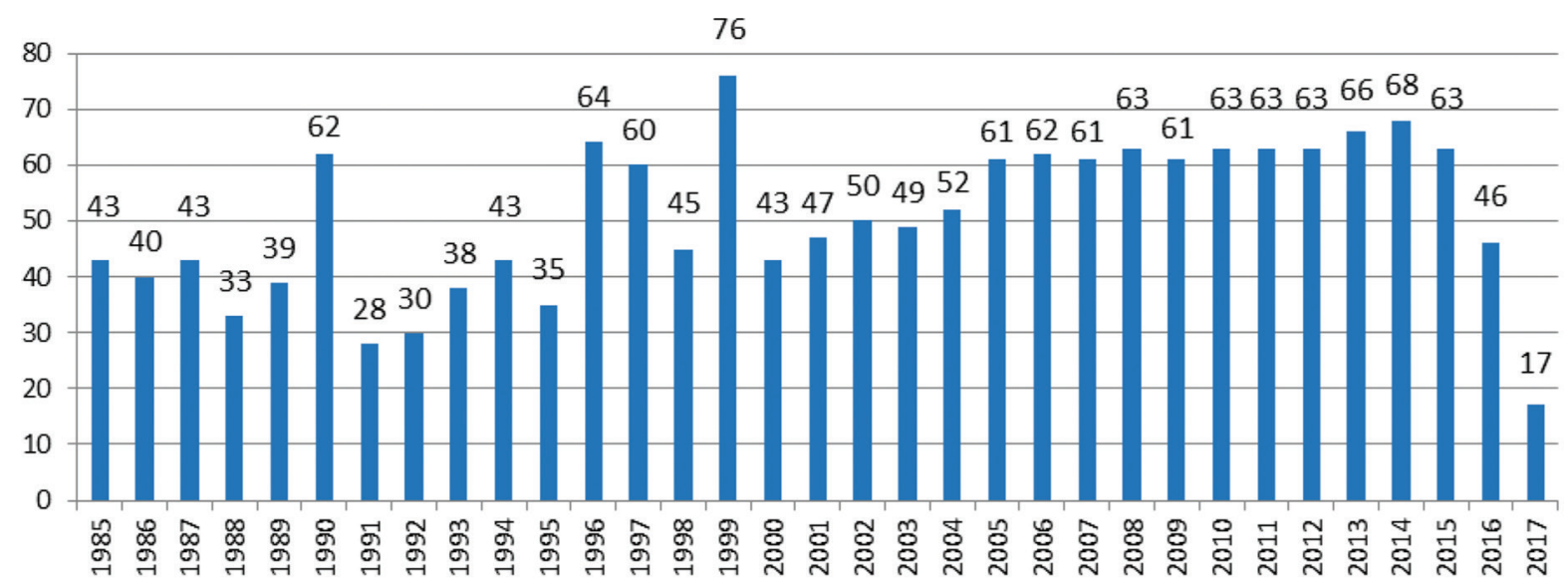

Citations received by Salud Mental

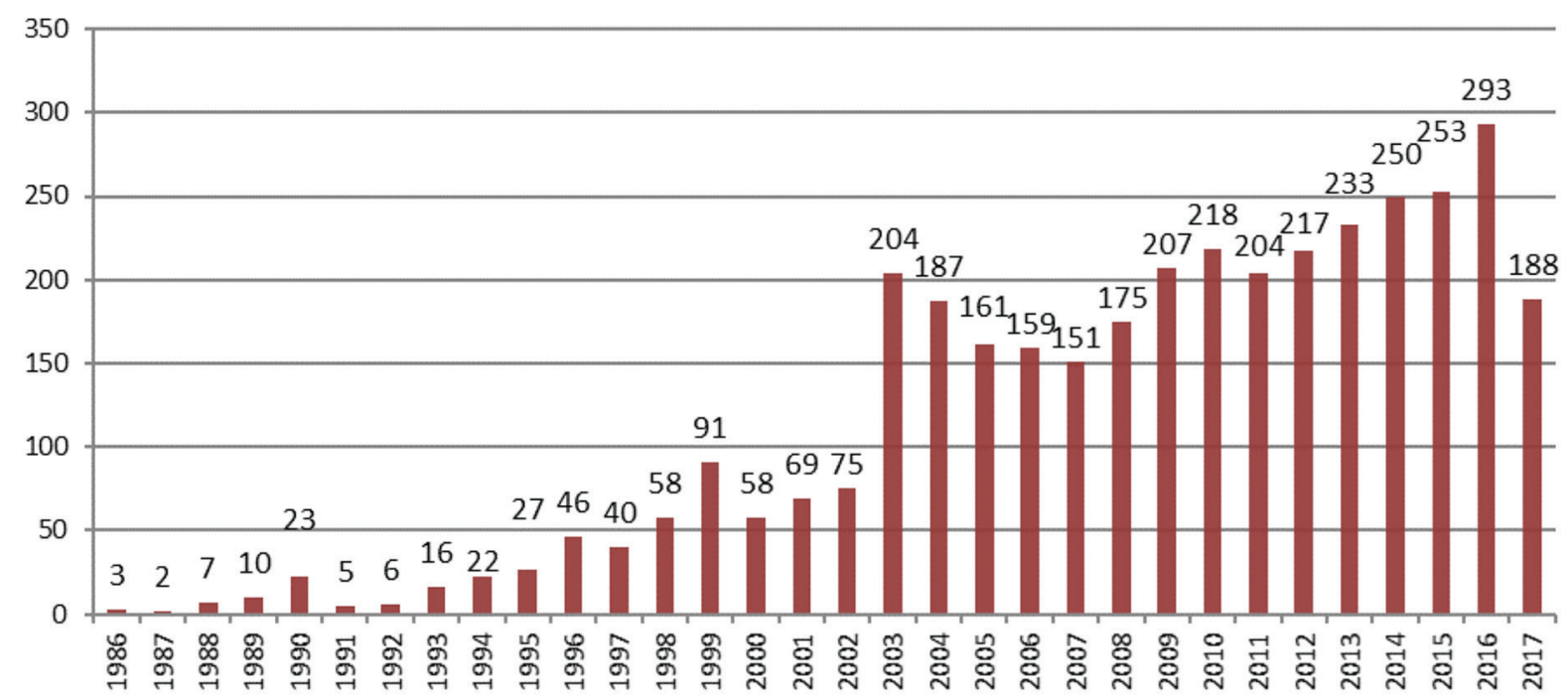

Figure 9. 1985-2017 documentary production analysis and number of citations 1986-2017, Salud Mental.

reducing waiting time for many manuscripts and guaranteeing their methodological quality.

The achievements accomplished in recent years are:

- Installation of the Open Journal Systems editorial manager to manage and publish the journal on a website of its own.

- Assignment of the digital object identifier (DOI), which gives our articles greater visibility and facilitates searches in databases.

- Incorporation of a systematic and rigorous methodological review process by the internal evaluation committee.

- Publication of indexed contents in English, in order to promote their dissemination and increase citations by the international scientific community.

- Implementation of a strategy for disseminating contents on social and academic networks.

- Participation of Salud Mental editorial team in projects for continuous improvement of the publication convened by Conacyt.

Salud Mental current challenge is consistent with that of other Latin American publications: to become a competitive option among the more than 3,000 journals of the Web of Science Social Science Citation Index (Journal Citation Report) (Fig. 10), which requires an updating process towards the trends and standards demanded by contemporary scientific 


\section{ralud mental}

reloc mentel

\section{Dirección de Enseñanza}

Departamento de Biblioteca Digital y Difusión Científica

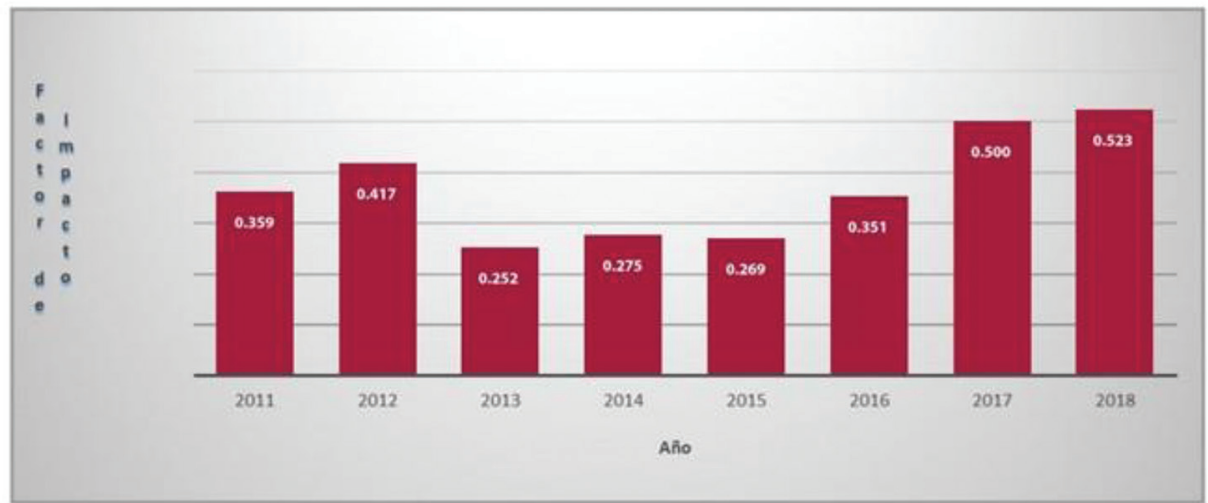

-FUENTE: InCites Journal Citation Reports Clarivate Analytics

\section{SALUD}

Figure 10. Salud Mental impact factor evolution from 2011 to 2018. publishing. For this purpose, a close relationship between authors and publishers is required.

\section{General conclusions}

The description of the six journals participating in this National Academy of Medicine of Mexico symposium documents the history and importance Mexican scientific journals have had in clinical research since the $19^{\text {th }}$ century. The challenges faced by some of these journals are mainly financial, which reflects the extremely low investment in research in Mexico that has been experienced for decades and that is envisaged as not too optimistic.

Recent Journal Citation Reports impact factors for 2019 show an increase for most analyzed journals, which nevertheless continues to be lower than 1.0 for half of them. Changes in these journals' impact factor are as follows: Archives of Medical Research, 2.093;
Revista de Investigación Clínica-Clinical and Translational Investigation, 1.192; Gaceta Médica de México, 0.581; Cirugía y Cirujanos, 0.264; Salud Pública de México, 1.647; Salud Mental, 0.689. Annals of Hepatology, another Mexican journal with an impact factor, stands at 2.125.

We hope that the prevailing need to promote clinical and biomedical research in Mexico as a result of the current COVID-19 pandemic, will give cause for our journals to increase the quality and originality of their contents and enable increasing their recognition among the national and international scientific communities, thus allowing them to be positioned in a place worthy of the academic stature of their researchers.

\section{Conflicts of interest}

The authors declare that they have no conflicts of interest. 


\section{Funding}

The authors did not receive any sponsoring to carry out this article.

\section{Ethical disclosures}

Protection of human and animal subjects. The authors declare that no experiments were conducted on humans or animals for this research.

Confidentiality of data. The authors declare that no patient data appear in this article.

Right to privacy and informed consent. The authors declare that no patient data appear in this article.

\section{References}

1. Somolinos-Palencia J. Contribuciones mexicanas a la investigación médica. Mexico: Universidad Nacional Autónoma de México; 1984.

2. Ramírez E. Nota preliminar sobre la citología del flujo menstrual. Rev Mex Biol. 1922;2:199.

3. Ramírez E. El ritmo sexual vaginal de la mujer. Rev Mex Biol. 1928;8:1.

4. Papanicolau GN. The sexual cycle in the human female as revealed by vaginal smears. Am J Anat. 1933;52:519.

5. Gómez-Dantés O, Retes L. Historia de Salud Pública de México. Salud Pública Mex. 1988;30:114-117.
6. Rodríguez-de Romo AC, Rodríguez-Pérez ME. Historia de la salud pública en México: siglos XIX y XX. Hist Cienc Saude-Manguinhos. 1998;5:293-310

7. López-Moreno S, Oropeza-Abúndez C. Salud Pública de México: evolución de una idea. Salud Pública Mex. 1999;41:442-443.

8. Cruz A. Nombran a Salud Pública de México como mejor revista científica del país. Mexico: Crónica [Online] Sep 08, 2017.

9. Rivera-Dommarco J, Shamah-Levy T, Barrientos-Gutiérrez T, Bautista-Arredondo S, Romero-Martínez M, Pelcastre-Villafuerte B, Torres-Pereda $P$. La salud de los mexicanos que habitan en localidades de menos de 100000 habitantes. Salud Pública Mex. 2019;61:709-715.

10. Lazcano-Ponce E, Oropeza-Abúndez C. Terremotos, salud y sociedad: lecciones aprendidas. Salud Pública Mex. 2018;60:S2-S5.

11. Barrientos-Gutiérrez T, Alpuche-Aranda C, Lazcano-Ponce E, Pérez-Ferrer C, Rivera-Dommarco J. La salud pública en la primera ola: una agenda para la cooperación ante Covid-19. Salud Pública Mex. 2020;62.

12. Vega-Vega O, Arvizu-Hernández M, Domínguez-Cherit JG, Sierra-Madero J, Correa-Rotter R. Prevención y control de la infección por coronavirus SARS-CoV-2 (COVID-19) en unidades de hemodiálisis. Salud Pública Mex. 2020;62:341-347.

13. Gutiérrez-Castrellón P. Current challenges on the generation and dissemination of scientific evidence in health and how to translate it to health decision making. Cir Cir. 2020;88:247-248.

14. Wolfram D, Want $P$, Hembree A, Park H. Open peer review: promoting transparency in open science. Scientometrics 2020.

15. Ross-Hellauer T, Görögh E. Guidelines for open peer review implementation. Res Integr Peer Rev. 2019;4:1-12.

16. Sokal AD. Transgressing the Boundaries: Towards a Transformative Hermeneutics of Quantum Gravity. Social Text. 1996;46/47:217-252.

17. Bogdanov G, Bogdanov I. Topological field theory of the initial singularity of spacetime. Class Quantum Gravity. 2001;18:4341-4372.

18. Schon JH, Kloc C, Batlogg B. Retraction note to: superconductivity in molecular crystals induced by charge injection. Nature. 2003;422:93.

19. Gallo RC, Essex M, Gross L (editors). Human T-cell leukemia/lymphoma virus. USA: Cold Spring Harbor Laboratory; 1984.

20. Mehra MR, Desai SS, Ruschitzka F, Patel AN. RETRACTED: hydroxychloroquine or chloroquine with or without a macrolide for treatment of COVID-19: a multinational registry analysis. Lancet. 2020. 